\title{
Bcl-Xs Adenovirus Vaccine
}

National Cancer Institute

\section{Source}

National Cancer Institute. BCl-Xs Adenovirus Vaccine. NCI Thesaurus. Code C28860.

A vaccine consisting of replication-defective recombinant adenovirus that encodes for Bcl-Xs with potential antineoplastic activity. Vaccination with Bcl-Xs adenovirus vaccine induces apoptosis in $\mathrm{Bcl}-2$ and $\mathrm{Bcl}-\mathrm{XL}$ positive cancer cells, resulting in decreased tumor growth while leaving normal cells unaffected. Bcl-Xs block the function of the protooncogenes $\mathrm{Bcl}-2$ and $\mathrm{Bcl}-\mathrm{XL}$ which are overexpressed in a variety of solid tumors and promote cancer cell survival by inhibiting apoptosis. ( $\mathrm{NCI04)}$ 